\title{
第 30 回人工透析研究会・般演題
}

\section{症 例 (2)}

座長 大沢 源吾 (川崎医科大学内科)

副甲状腺腫摘出術後に完全房室ブロックの改善を認めた慢性透析患者の 1 例

済生会横浜市南部病院透析センター 尼ケ崎安紘, 北野まり子, 岡坂スエ子

菅原 郁子, 武藤 雪枝

同循環器科義井譲

同外科五島 英迪

東神クリニック 高口 直明, 川田 征一

成人型多発性囊胞腎患者の末期像に対する臨床的検討

尚腎会高須クリニック附属安芸診療所

竹中 章, 塩津 智之, 乾 毅,

桑原 和則, 寺尾 尚民

慢性血液透析患者にみられた興味ある経過を示した壊死性血管炎の 1 剖検例

$\begin{array}{cllll}\text { 聖橋クリニック } & \text { 星野 } & \text { 正信, 阿部 薫 } & \\ \text { 東京大学第 } 1 \text { 内科 } & \text { 西 } & \text { 忠博, 鈴木 慶二, 野中 達也 } \\ & \text { 中尾 } & \text { 彰秀, 桑田 昇治 } \\ \text { 同病理 } & \text { 岡 } & \text { 輝明, 浦野 順文 }\end{array}$

血液透析患者にみられた敗血症 4 例の臨床的検討

沖繩県立中部病院内科上原元, 田港 朝丈, 宮里不二彦

頻回に意識消失発作を呈し内シャントの関与が疑われた 1 症例

$\begin{array}{rrr}\text { 済生会中津病院内科 } & \text { 湯川 } & \text { 進 } \\ \text { 医誠会病院外科 } & \text { 谷岡 } & \text { 恒雄 } \\ \text { 大阪厚生年金病院内科 } & \text { 白井 } & \text { 大禄 }\end{array}$

心外膜炎合併例の診断および治療の検討

$\begin{array}{llll}\text { 重井病院内科 } & \text { 森脇 } & \text { 和久, 芳野 健, 杉本茂 } \\ & \text { 難波 経雄, 重井 博 }\end{array}$

多囊胞化萎縮腎とその合併症に関する若干の検討

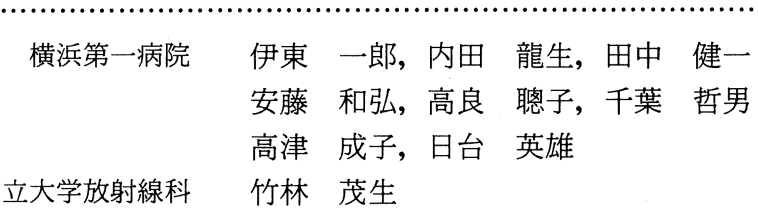

討 論 


\section{副甲状腺腫摘出術後に完全房室ブロックの改善を認め た慢性透析患者の 1 例}

尼ヶ崎安紘 北野まり子 岡坂スエ子 菅原郁子

武藤 雪枝 義井譲 ${ }^{*}$ 五島 英迪 ${ }^{* *}$ 高口 直明***

川田 征一***

済生会横浜市南部病院透析センター 同循環器科*同外科** 東神クリニック***

はじめに：副甲状腺機能立進症を伴う慢性血液透析患者 で, 完全房室ブロックを併発し, 副甲状腺腫摘出術後に 1 度 房室ブロックまで改善した症例を経験したので報告する。

症例：48 歳男性, 慢性腎炎による腎不全にて昭和 55 年 6 月より血液透析を開始し, 昭和 58 年 3 月より両下肢痛出現 し, 昭和 59 年 7 月右頸部腫瘤を認め入院す. 全身の搔痒感強 く, red eye を呈し, 肺炎を併発しており, 入院後完全房室 ブロックを来した．副甲状腺 3 腺および腺腫摘出術施行し, その後自覚症状は消失し, 貧血は著明に改善し, 血中 $\mathrm{Ca}$, ALP, PTH 濃度は低下し, 心電図上, 1 度房室ブロックまで 改善す.

まとめ：透析患者において, 副甲状腺機能立進症によると 思われる房室ブロックの報告は全例死亡しており，剖検にて 伝導系および心筋内の Ca 沈着を証明している. 本例は完全 房室ブロックを呈したにも拘らず，術後改善した貴重な症例 と考え報告する。

\section{成人型多発性囊胞腎患者の末期像に対する臨床的検討}

竹中 章 塩津 智之 乾 毅 桑原 和則

寺尾 尚民

尚腎会高須クリニック附属安芸診療所

成人型多発性囊胞腎（以下 PKD と略す）患者 64 例につい て透析症例 19 例を中心に臨床的検討を加えた. PKD 患者の 男女比は $1: 1$, 診断平均年齢は 45.9 歳, 診断から透析導入 までの平均期間は約 9 年, 透析患者の平均年歯令は 57.3 歳, 平 均透析期間は 4 年 9 力月であった. 遺伝性は $61.8 \%$, 他藏器 囊胞の合併は $69.4 \%$ と高率に認められた。

透析症例について検討を加えた. PKD 患者は他原疾患 (以 下 non-PKD と略す) 患者に比較し, $\mathrm{Ht}$ 值, $\mathrm{RBC}, \mathrm{Hb}$ 值は 有意に高值であったが, erythropoietin には有意差は認めら れなかった。平均血圧では有意に低かった。シャントトラブ ルでは diabetic nephropathy, glomerulonephritis 患者に対 し，有意差は認められなかった. PKD 患者の合併症として UTI, intracytic abscess あるいは perinephric abscess が, それぞれ $29.2 \%$ ，25\%に認められた。PKD 患者の腎容積を summation of areas technique を用いて CT-scanより測定 したが, 最小 $251 \mathrm{~cm}^{3}$, 最大 $3,575 \mathrm{~cm}^{3}$, 左右差は認められな かった．急疫能を比較するため PPD, PHA 皮内反応を施行 したが, non-PKD 患者に比較し有意差は認められなかった。 PKD 患者の死亡例を検討したが，死亡原因には特異性は認 められなかった。

以上より, PKD 透析症例は non-PKD 透析症例に比較し, 貧血はより軽度であるが，低血圧や UTI， intracystic abs- cess, perinephric abscess 等の合併症が多く, 注意深い経過 観察が必要であると考えられた。

\section{慢性血液透析患者にみられた興味ある経過を示した壊 死性血管炎の 1 剖検例}

星野 正信 阿部 薫 西 忠博* 鈴木 慶二*

野中 達也* 中尾 彰秀* 桑田 昇治* 岡 輝明**

浦野 順文**

聖橋クリニック 東京大学第 1 内科* 同病理**

症例 : 51 歳男性. 昭和 51 年会社健診時蛋白尿を指摘. 昭和 55 年暮から腎機能が急激に低下し, 昭和 56 年 1 月血液透析 を開始. 昭和 57 年 5 月微熱, 軽度好酸球増多, 右中肺野の円 形陰影が出現し抗結核剤を投与, 約 3 力月の経過で消失した。 昭和 58 年 5 月発熱, 多関節痛, 筋痛, 両眼ぶどう膜炎ととも に両側性に多彩な胸部陰影が出現した。鼻粘膜生検, 皮膚生 検, TBLBで血管炎の所見は得られなかったがプレドニゾロ ン $60 \mathrm{mg} /$ 日で治療開始したところ著明な改善がみられ約 2 力月後退院した.プレドニゾロン漸減中同年 12 月くも膜下 出血で急死した. 剖検では右椎骨動脈に $0.2 \mathrm{~cm}$ 径動脈瘤の破 裂があり肉芽形成反応を伴う壊死性血管炎が認められた。そ の他, 肺, 睪丸, 食道, 脾などに新・旧の壊死性血管炎が認 められた. 腎は著明な萎縮腎で血管炎の所見は認めなかった. 本症例は気管支喘息を欠く点が定型例と異なるが, 臨床検査, 病理組織所見およびステロイドが著効を示したことからアレ ルギー性肉芽腫性血管炎に近い壊死性血管炎と考えられた。

我々は慢性血液透析患者に感染症との鑑別困難な肺症変を 呈し興味ある経過を示した壊死性血管炎の 1 剖検例を経験し た。血液透析患者の経過中にみられる不明熱や肺病変の鑑別 診断上，本例のような血管炎も稀ながら存在することを考慮 する必要があると思われる。

\section{血液透析患者にみられた敗血症 4 例の臨床的検討}

上原 元 田港 朝丈 宮里不二彦

沖繩県立中部病院内科

目的：血液透析（以下 HD）患者の敗血症 4 例を経験した ので臨床的検討を行った。

方法：当透析室が開設された昭和 57 年 6 月から 60 年 1 月 までの 2 年 8 力月間に 4 例の敗血症の発生があり, その臨床 症状，起炎菌，合併症，治療法等について検討した。

結果：原疾患は不明熱の既往のある悪性高血圧症，持続性 の低補体を伴う SLE, 難治性腹膜炎のため CAPD から $\mathrm{HD}$ に移行した CGN, プレドニン $5 \mathrm{mg}$ を投与中の RA による腎 アミロイドーシス各 1 例であり， 4 例とも immunocom promised host を思わす下地があった。全例に悪寒戦慄を伴 う高熱がみられた。また全例に白血球增多, CRP 強陽性, 赤 沈の充進がみられた。起炎菌は 4 例ともすべて異なっており, 各々 Staphylococcus Aureus, Neisseria Meningitidis, E coli Aeromonas Sobria, Streptococcus Pneumoniae であっ た. 菌の侵入門戸は肺炎から推定された 1 例を除いて他の 3 例は不明であった。合併症として, Staph. Aureus 例で内シャ 
ント吻合部の Mycotic Aneurysm および肺の Septic Emboli がみられた. Neisseria 例で Septic shock がみられた。 抗生物質は発症初期には CEZ または CET と Tobramycin の 2 郕投与が行われ, 菌が同定された後, 菌の感受性に応じ てバンコマイシンや水溶性ペニシリンにきりかえられてい た。全例軽快し死亡例はなかった.

総括：HD 患者に悪寒戦慄を伴う発熱がみられたら，敗血 症も念頭に入れて迅速に対処すべきである．起炎菌には一定 の傾向はなかったので, 発症初期にはセファロスポリン系と アミノグリコシド系の 2 珮投与がよいと思われた。

\section{頻回に意識消失発作を呈し, 内シャントの関与が疑われ た 1 症例}

湯川 進 谷岡 恒雄* 白井 大禄**

済生会中津病院内科 医誠会病院外科*大阪厚生年金病 院内科**

目的：種々のブラッドアクセスが心・血管系に及ぼす影響 については多くの報告があるが，脳循環に言及しているもの は少ない. 我々は頻回に意識消失発作を呈したが, 内シャン 卜再手術によるシャント量減少とともに症状の発生を認めな くなった 1 症例を経験した。この症例よりブラッドアクセス が脳循環に及ほす影響について述べてみたい。

症例・結果：症例は 34 歳男性. 右前腕に内シャントを側々 吻合で形成されたが, 術後 1 年 6 力月頃より意識消失発作を 頻回に呈するに至った。吻合部に巨大な血管瘤を形成してお り, 約 1 年後これを除去し端々吻合に変更したところ意識消 失発作の発生は認められなくなった。術後であるが, 腕頭動 脈の血管造影や超音波ドップラー法による頸動脈の血流を検 討したところ, 右頸動脈領域の循環不全を示唆するデー夕が 得られた。

総括：右上肢に設置されたブラッドアクセスの血流（シャ ント量）が多ければ，右頸動脈領域の循環不全を生じる可能 性がある。

\section{心外膜合併例の診断および治療の検討}

森脇 和久 芳野 健 杉本 茂 難波 経雄
重井博

\section{重井病院内科}

当院における心外膜炎合併例の診断および治療法の歴史を 述べ, 昭和 55 年より施行している HDF, $\gamma$-gl 製剤等の併用 療法の有用性について検討した。

対象: 昭和 43 年より 59 年まで当院で透析した腎不全患者 470 名のうち心外膜炎を合併した 23 名 (5.1\%). 男 12 , 女 11. 合併時平均年齢 $42.5 \pm 13.0$ 歳. 透析導入時および導入 1 年以 内の合併 8 例 (34.7\%), 維持透析期の合併 15 例 (65.3\%).
維持透析期合併例の導入より発生までの平均月数は $37.0 \pm$ 22.2 力月.

診断：23 名全例で CRP 陽性と心機能比の増大を認めた。 49 年までの 6 名は心膜摩擦者の聴取がきめ手となったが, 50 年以後の 17 名では UCG, リニア走査も併用した. 血清ウイ ルス抗体価を測定した 3 例でコクサッキー,インフルエンザ, サイトメガウイルスの抗体価の上昇を認めた。試験穿刺を施 行した全例で心囊液は血性であった。

合併前身体状況：シャント感染またはトラブルを 7 例, 肝 機能異常を 6 例, 胃癌術後 1 例, 肺癌 1 例, 非定型的抗酸菌 症を 1 例認めた。

治療・転帰： 54 年以前の 14 例では頻回透析および心膜切 開ドレナージを主として施行（2 例は心タンポナーデで死 亡), 平均治瘜日数は $53.5 \pm 46.2$ 日であった. 55 年以後の 9 例では HDF および $\gamma-\mathrm{gl}$ 製剤を主として使用（3 例が心夕 ンポナーデ, 癌性心外膜炎, 消化管出血で死亡), 平均治痖日 数は $43.6 \pm 25.4$ 日であった。

考案: 心外膜炎の発生原因は不明であるが, 殺菌, ウイル スの先行感染, 手術等のストレスによる異化穴進, 中分子物 質の関与等が示唆されている。この事より心外膜炎を早期に 診断し, HDF, $\gamma$-gl, 消炎剂, 抗生剂等の併用療法は有効な手 段と考えられた。

\section{多襄胞化萎縮腎とその合併症に関する若干の検討}

伊東 一郎 内田 龍生 田中 健一 安藤 和弘

高良 聰子 千葉 哲男 高津 成子 日台 英雄

竹林 茂生*

横浜第一病院 横浜市立大学放射線科*

目的：血液透析療法の進歩により, 長期生存の慢性腎不全 患者が増えるにつれて, 残存腎における囊胞形成 (ACDK) が注目されるようになった。 今回, 我々は超音波断層装置 (US), CT scan を用いて画像診断を行い, ACDK に関する 若干の検討を加えたので報告する．また, ACDK に腫瘍, 後 腹膜出血などを合併した 5 例についても症例呈示する.

方法: 当院およびその関連施設の血液透析患者 311 名を対 象として, US, CT scan ょり ACDK の検索を行い, 囊胞の 形成率, 原疾患や透析年数との関係, 腫瘍化の頻度などにつ いて検討した。

結果: ACDK は透析 3 年以上の症例の $21 \% 65$ 例に認めら れ, 透析期間が長くなるほど発生率が増加していた。このう ち 4 例には腫瘍が合併しており (renal cell carcinoma 3 例, angiomyolipoma 1 例）腎摘出術が施行された。また, 特発 性腎破裂により後腹膜出血をおこした興味深い 1 例にも遭遇 した。

総括：ACDK とその合併症について検討した. 
大沢 尼ヶ崎先生のご発表は副甲状腺摘出によって完全ブ ロックが改善されたという症例でございますが, ご追加， あ るいはご発言ございませんでしょうか.

この症例はかなり急速に心電図の回復ということがあるわ けでございますね。

尼ヶ崎 ブォルター心電図で何回か経過を見ているわけで すけれども, 術前はほとんど完全ブロックで, 翌日には 2 度 から 3 度, あるいは 1 度のが 24 時間の間にかなり入り乱れて おりまして，5病日にほぼ 1 度の AV ブロックになりました けれども, ときどき 2 度のものが混じると. それから術後 12 日目ぐらいからは大体 1 度の状態に戻りました。

大沢 そうするとやはりメカニズムとしては直接的なもの

尼ヶ崎 血中のカルシウム濃度そのものとしますと回復が 遅いということと, もう半年以上たつのですけれども, いま だに 1 度の AV ブロックはとれていないということを考え ますと, やはり伝導系, ないしは心筋内にカルシウムの沈着 があるのではないかと思われます.ただ,だんだんウォッシュ アウトされていきますと将来完全に消失する可能性もあるの ではないかと思っておりますけれども, 一応組織に沈着して いくのではないかと推測しているわけです.

篠田 (金沢医科大学腎臓内科) 竹中先生のご講演でははっ きり言われませんでしたが，相当長く見ておられるようです が，悪性腫瘍の合併はなかったのでございますね。

竹中 今回はありませんでした。

篠田 それと腎容積をお測りのようなのですが, 血液透析 を開始する前とあととで腎容積——もろん相当透析をやら なければ変わらないと思いますけれども一が減少するとい うようなことを見られたでしょうか.

竹中 今回，透析の前にはほとんど CT を撮っていない例 が多くて，その辺の検討は行っておりません.

大沢 エリスロポエチンにはあまり有意差がなくて，へマ トクリットは有意に高かった，そのあたりの解釈をどうな さっておりますか.

竹中 エリスロポエチンの測定方法とか, 今回ブリストル の方へ頼みましたので, 赤血球凝集抑制の方で調べておりま す. その辺の正確さというのもあるだろうと思いますけれど も, いま radioimmunoassay とかそっちの方で測れるように なってきていると思いますので, そちらの方の測定とかいろ いろ検討したいと思っております。

大沢 初期, 51 年ころの蛋白尿発見時には生検とか, そう いった材料はないのですか.

星野 会社の健康診断でたまたま発見されまして, 血沈六 進とか, そういう炎症反応なども特にございませんで, 臨床 症状は特にございませんでした。
大沢 そうするとそのときがクレアチニン 1.8 ぐらいだっ たですね。

星野 そうです.

大沢 急激なとおっしゃったけれども，あれは一応慢性腎 炎としての自然経過というふうに…..

星野 $51 \sim 55$ 年までは一応 2 前後で安定していたのです けれども， 55 年暮れから $2 ， 3$ 力月のうちに急速に uremia に陷りました。

大沢 あと透析中に抗結核剤などをお使いになっています ね.

星野 第 1 回目に結核を疑って一一細菌学的には陰性だっ たのですが，抗結核剤を投与しました。いまから考えてみま すと，自然緩解という経過だと思います。

大沢上原先生，そうしますとこういう sepsis を起こすよ うなものにはやはり何か少し準備状態というものが人工的に もありそうだと.

上原 先ほどもスライドに出したように，そうだと思いま す.

大沢 それから発熱というのがよくおこるのだけれども， その際, 先生の例では全部, 悪寒, 戦慄ということを重視し たいということでございますか.

上原 そうです。

桑原（高須クリニック） ただいまの発表をお聞きします と, いわゆる anoxia でそういうことが起こったということ でしょうか.

湯川よくわかりませんが，いろいろ検討したのですけれ ども, 初め意識消失が起こりまして狭心症の症状を訴えまし たので, 狭心症様ではないかと考え心電図とか測定しており まして, あと脳波もとり, いろいろしたわけです。精神神経 科も受診させ, 癲痱ではないだろうけれど一応, 廎癎の薬を やったらどうかというアドバイスがありまして, それで中止 して，一応こうなったということで，こういう症例もあると いうことを提示させていただいて先生方のご意見をお伺いし たいということでございます。

桑原 シャントをつくることによってどうして総頸動脈の 血流が少なくなるか, あるいは行かなくなるかというのがわ からないのですが, それをどういうふうにお考えでしょうか.

湯川 理解に苦しむこともあるのですが, 䁰動脈の血流を 測ってもらったわけです. シャント開放時には左右差はなく て, シャント血流を遮断するとシャント反対側方の右の頸動 脈および椎骨動脈の血流が $20 \%$ ほどアップすると.ですから 血流の欠乏ではなくて, 何か循環不全を起こしているのでは ないかなと思うのですが，その辺はよくわからないのです.

桑原 反対側の頸動脈の血流は測っておられますか. 
湯川 専門科へ依頼しましたので，事前にそういうことを よく説明しませんでして，血流を測ってないのですが，シャ ント開放時に左右差はなく, 閉塞すると, ある方が $20 \%$ 増加 するという結果が返ってきました。

大沢 またいろいろご検討いただいて次に発表していたた゚ きたいと思います.どうもありがとうございました。

大沢 森脇先生, 慢性透析中の心外膜炎の合併およびその 治療ということでございますが，ご発言，ご追加ございませ んでしょうか.

消炎剤よりもグロブリン製剤が有効だと，この統計からそ ういうふうに考えているわけですか.

森脇 消炎剂も全例使っていますし, 絶対に効くという確 証はありませんけれども，いろいろな可能性を考えていろい ろ併用するのはいいのではないかと思っています。

大沢 伊東先生のご発表は透析持続にまつわる囊胞化とい
う大きな問題だと思います．何かご発言，ご追加ございます でしょうか.

石川 (金沢医科大学腎臓内科) renal cell carcinoma が 3 例ということで, renal cell carcinoma というのは多囊胞と 関係して発生するというふうに考える方が多いのですけれど も, 先生の症例 2 の angiomyolipoma に関しては, 多霊胞の 関連というものはいかがでしょうか, 腫瘍発生という面に関 して, 全く偶然の合併なのか, あるいは何か関係があるとい うふうに㧍えでしょうか。

伊東 明確に関連しているというふうには即断できないと 思います。

石川 単に偶然の合併ともお考えにならないですか.

伊東 その辺のことは, 頻度の割合の差ですね. angiomyolipoma がどれくらい ACDK に合併してくるという今後の 課題でわかると思うのですけれども.

石川いままでにはそういう報告はないみたいですね。

\section{検查室に最も信頼おける便利な}

数々を提供している富士工業

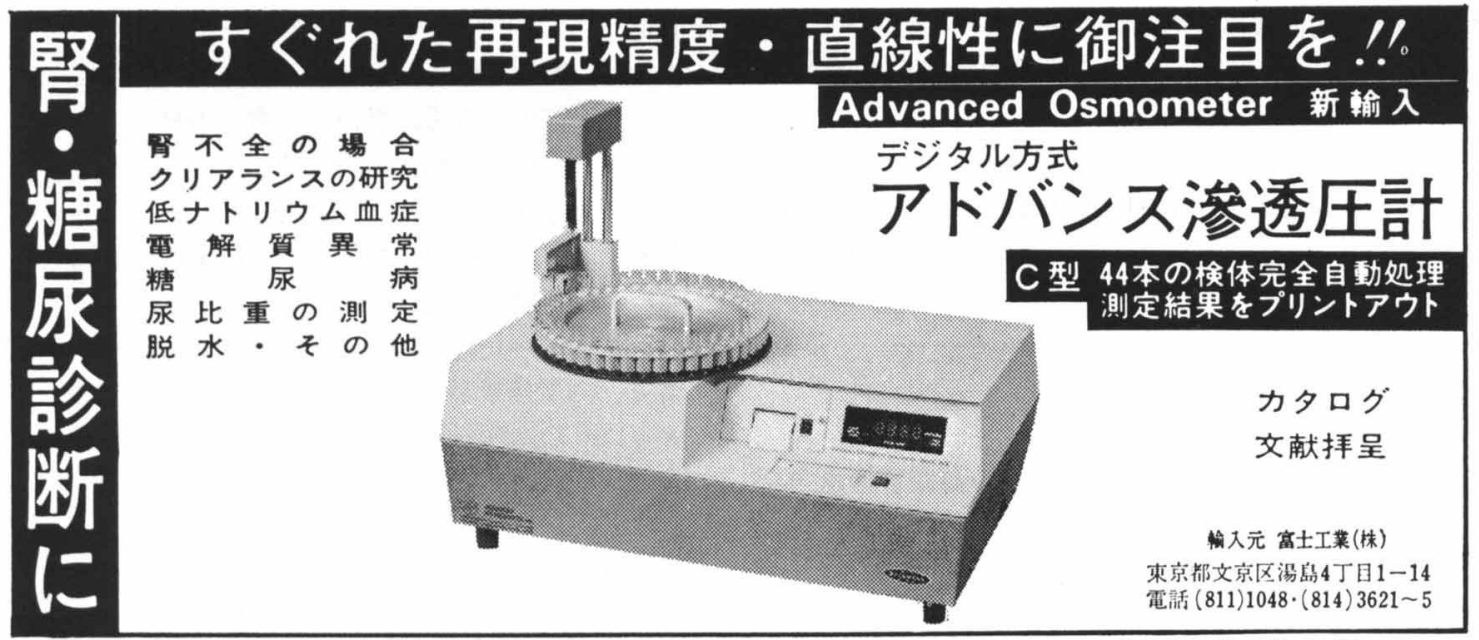

（全国有名器惦で取报）

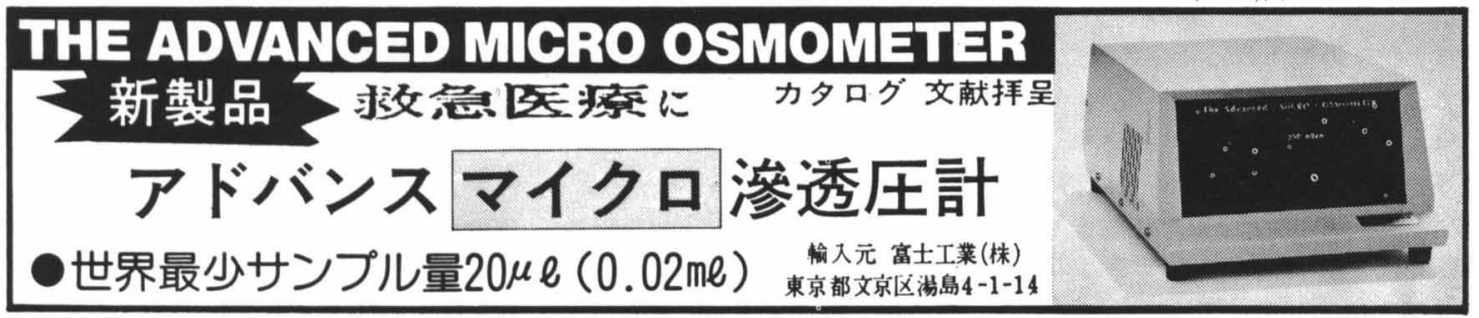

